\title{
Kurikulum Pendidikan Islam Multikultural (Analisis Tujuan Taksonomi dan Kompetensi Peserta Didik)
}

\author{
Tri Wahyudi Ramdhan \\ Dosen Sekolah Tinggi Agama Islam Darul Hikmah Sumenep - Indonesia \\ Email: wahyudi@darul-hikmah.com
}

\begin{abstract}
This article will to discuss the curriculum of multicultural Islamic education. Considering the curriculum discussion is very diverse, from a narrow and broad scope, however in general the scope or component of the curriculum consists of elements (1) goals; (2) content or material; (3) material delivery process or system; and (4) evaluation. And in this paper not all elements of the curriculum are of concern, the discussion will only be focused on elements of objectives that will be associated with multicultural Islamic values. Thus the focus that is the main target of the author in this discussion is about goals, precisely about the hierarchy of the formulation or formulation of educational goals, and taxonomy to develop learning objectives and the preparation of instruments for evaluation of multicultural Islamic learning outcomes.
\end{abstract}

\begin{abstract}
Abstrak
Pada tulisan ini membahas tentang kurilum pendidikan Islam multikultulral. Mengingat pembahasan kurikulum sangat beragam, dari cakupan sempit maupun luas, namun demikian secara umum cakupan atau komponen kurikulum terdiri dari unsur (1) tujuan; (2) isi atau materi; (3) proses atau sistem penyampaian materi; dan (4) evaluasi. Dan dalam tulisan ini tidak seluruh elemen kurikulum tersebut menjadi perhatian, pembahasan hanya akan difokuskan pada elemen tujuan yang akan dihubungkan dengan nilai-nilai Islam multikultural. Dengan demikian fokus yang menjadi sasaran utama penulis dalam pembahasan ini adalah mengenai tujuan, tepatnya tentang hirarki penyusunan atau perumusan tujuan pendidikan, serta taksonomi untuk menyusun tujuan pembelajaran serta penyusunan intrumen evaluasi hasil pembelajaran Islam multikultural.
\end{abstract}

Keywords: Multicultural Islamic Education, Taxonomy, Competence 


\section{A. Pendahuluan}

Sebagaimana banyak dibahas dalam kajian-kajian tentang pendidikan atau kajian mengenai pengembangan kurikulum, kurikulum mempunyai pengertian yang cukup kompleks, dan sudah banyak didefinisikan oleh para pakar kurikulum. Kajian pendidikan tidak dapat dipisahkan dari kajian kurikulum disebabkan keduanya memiliki hubungan fungsional, artinya membahas pendidikan berarti membahas tentang tujuan pendidikan, membahas tujuan terkait dengan cara, sarana dan metode juga sejauhmana tujuan tercapai. Secara umum penjelasan mengenai kurikulum dijelaskan secara etimologi maupun secara epistemologis, kemudian dilanjutkan dengan pembahasan pengertian kurikulum dari para pakar.

Demikian pula yang kita temukan dalam kajian-kajian tentang konsep-konsep tentang pendidikan, pendidikan Islam maupun pendidikan Islam multikultural. Konsep tersebut menjadi landasan tema pokok pembahasan tulisan ini, yaitu mengenai kajian tujuan dalam kurikulum pendidikan Islam multikultural.

\section{B. PEMBAHASAN}

\section{Kurikulum: Pengertian dan arah tujuan}

Secara harfiah kurikulum berasal dari bahasa latin, curriculum yang berarti bahan pengajaran. Ada pula yang mengatakan kata tersebut berasal dari bahasa Perancis courier yang berarti berlari. ${ }^{1}$ Kata kurikulum selanjutnya menjadi suatu istilah yang digunakan untuk menunjukkan pada sejumlah mata pelajaran yang harus ditempuh untuk mencapai suatu gelar atau ijazah. Pengertian ini sejalan dengan pendapat Crow and Crow yang mengatakan bahwa kurikulum adalah rancangan pengajaran yang isinya sejumlah mata pelajaran yang disusun secara sistematis yang diperlukan sebagai syarat untuk menyelesaikan suatu program pendidikan tertentu. ${ }^{2}$ Selain itu ada pula yang berpendapat bahwa kurikulum adalah sejumlah mata pelajaran yang disiapkan berdasarkan rancangan yang sistematik dan koordinarif dalam rangka mencapai tujuan pendidikan yang ditetapkan. ${ }^{3}$ Dengan demikian sebagaian lagi berpendapat bahwa kurikulum pada hakikatnya adalah rancangan mata pelajaran bagi suatu kegiatan jenjang pendidikan tertentu, dan dengan menguasainya seseorang dapat dinyatakan lulus dan berhak memperoleh ijazah.

\footnotetext{
1 S. Nasution. Pengembangan Kurikulum, Bandung: Citra Adirva Bakti 1991 cet. ke-4. hal. 9.

2 Crow and Crow, Pengantar Ilmu Pendidikan, Yogvakarta: Rake Sarasin 1990, edisi III, hal.75.

3 Abdurrahman Saiih Abdullah, Educational Theory a Quranic Outlook, Makkah alMukarramah: Umm al-Qura University, t.t., hal. 123.
} 
Sebagai gambaran cakupan keluasan pembahasan mengenai kurikulum, dari berbagai literatur tentang pembahasan kurikulum, cakupan pembahasan kurikulum terkait dengan 1). Landasan Filosofis, didalamnya membahas keterkaitan kurikulum dengan aliran-aliran filsafat klasik - modern : perenialis, essensialis; Pribadi: progresif, romantik; Interaksional: rekonstructionism, Teknologi Pendidikan: teknologi, essensialis, progressif. 2). Landasan Teori, didalamnya membahas keterkaitan dengan; Teori belajar, model dan desain kurikulum yang digunakan. 3). Filosofi dan teori kurikulum yang digunakan harus disesuaikandengan tujuan pendidikan nasionaldan tujuan pendidikan suatu jenjang pendidikan. 4). Dari aspek filosofi yang digunakan akan memperlihatkan apakah kurikulum tersebut dikembangkan untuk menjawab kebutuhan masyarakat dalam pengembangan ilmu, teknologi, agama, sosialbudaya-ekonomi, dsb. 5). Kurikulum dalam Dimensi Dokumen Berkenaan dengan: Tujuan, isi (materi), Kegiatan Belajar, dan Penilaian. 6). Kurikulum dam dimensi proses (pelaksanaan pembelajaran) perlu memperhatikan faktor-faktor yang berhubungan dengan implementasi kurikulum, didalamnya terkait dengan; SDM, fasilitas, lingkungan, pendanaan, kepemimpinan, dsb. 7). Kurikulum dalam dimensi hasil berkaitan dengan Output dan outcome yang dihasilkan.

Banyak pakar memberi pendapat tentang kurikulum baik dalam pengertian luas dan sempit, tetapi penulisan ini mengutip menurut Sukmadinata yang menyatakan kurikulum merupakan rancangan pendidikan yang merangkum semua pengalaman belajar yang disediakan bagi siswa di sekolah. Dalam kurikulum terintegrasi filsafat, nilai-nilai, pengetahuan, dan perbuatan pendidikan. Selanjutnya dijelaskan untuk memahami konsep kurikulum setidaknya ada tiga pengertian yang harus dipahami, yaitu; (1) kurikulum sebagai substansi atau sebagai suatu rencana belajar; (2) kurikulum sebagai suatu system yaitu sistem kurikulum yang merupakan bagian dari sistem persekolahan dan sistem pendidikan, dan sistem masyarakat; (3) kurikulum sebagai suatu bidang studi yaitu bidang kajian kurikulum yang merupakan bidang kajian para ahli kurikulum, pendidikan, dan pengajaran. ${ }^{4}$

Namun demikian pengertian kurikulum tersebut diatas, yang menekankan pada penguasaan bahan pelajaran, yang pada kenyataannya selalu berkembang dan berubah sesuai dengan tuntutan kemajuan sudah ketinggalan zaman. Misalnya pendapat Saylor dan Alexander sebagaimana dikutip S. Nasution, misalnya

4 Sukmadinata, Nana, 2004, Landasan Psikologi Proses Pendidikan, Rosdakarya, Bandung, hlm. 150 
mengatakan bahwa kurikulum bukan hanya sekedar memuat sejumlah mata pelajaran, akan tetapi termasuk pula di dalamnya segala usaha sekolah untuk mencapai tujuan yang diinginkan, baik usaha tersebut dilakukan di lingkungan sekolah maupun di luar sekolah. ${ }^{5}$ Demikian pula salah satu pendapat ahli pendidikan Islam, misalnya pendapat Hasan Langgulung. Menurutnya, kurikulum adalah sejumlah pengalaman pendidikan, kebudayaan, sosial, olah raga, dan kesenian baik yang berada di dalam maupun di luar kelas yang dikelola oleh sekolah. ${ }^{6}$

Dari beberapa pendapat tersebut diatas, jelaslah bahwa pengertian kurikulum mengalami perkembangan yang semula menitik beratkan pada sejumlah mata pelajaran yang diajarkan di sekolah, berkembang ke arah semua pengalaman peserta didik baik di lingkungan sekolah maupun di luar lingkungan sekolah. Dari perluasan pengertian kurikulum tersebut timbullah pemaknaan dan kesadaran baru bahwa sekolah sendiri tidak mampu mencapai tujuan pendidikan, atau memberikan kompetensi tanpa dukungan dari masyarakat luar sekolah.

Pengertian kurikulum yang menjadi acuan dalam tulisan ini pada intinya mengacu pada pengertian kurikulum yang dipakai dalam pendidikan formal, yaitu pengertian sesuai dengan Pasal 1, ayat 19 UUSPN No. 20 tahun 2003, kurikulum adalah seperangkat rencana dan pengaturan mengenai tujuan, isi, dan bahan pelajaran serta cara yang digunakan sebagai pedoman penyelenggaraan kegiatan pembelajaran untuk mencapai tujuan pendidikan tertentu. ${ }^{7}$

Dalam arti sempit kurikulum ditafsirkan sebagai materi pelajaran, sedangkan pengertian yang luas ditafsirkan sebagai segala upaya yang dilakukan di bawah naungan sekolah. Cakupan pengertian kurikulum di atas, baik yang luas maupun sempit, pada dasarnya menyiratkan hal yang sama yaitu interaksi antara pelajar dan guru-guru untuk mencapai tujuan pendidikan. Dapat dipahami bahwa kurikulum adalah produk dari perencanaan yang disusun secara terstruktur untuk suatu bidang studi. Sehingga kurikulum memberikan pedoman dan instruksi untuk mengembangkan strategi pembelajaran. Materi dalam kurikulum harus diorganisasikan dengan baik agar sasaran (goals) dan tujuan (objectives) yang ditetapkan dapat tercapai. Dan dalam konteks pendidikan nasional tujuan kurikulum adalah untuk mempersiapkan manusia Indonesia agar memiliki kemampuan hidup sebagai pribadi dan warga negara yang

\footnotetext{
${ }^{5}$ S. Nasution, Pengembangan Kurikulum..., hal. 9.

${ }^{6}$ Hasan Langgulung, Asas-asas Pendidikan Islam, Jakarta: Pustaka Al-Husna cet. ke-1,1987, hal. 483-484.

7 Pasal 1, ayat 19 UUSPN No. 20 tahun 2003
} 
JURNAL PIWULANG, Vol. I No. 2 Maret 2019, 121-136

beriman, produktif, kreatif, inovatif, dan afektif serta mampu berkontribusi pada kehidupan bermasyarakat, berbangsa, bernegara, dan peradaban dunia. ${ }^{8}$

Setiap kurikulum membentuk suatu desain yang menggambarkan pola organisasi dari komponen-komponen kurikulum yang terdiri dari (1) tujuan; (2) isi atau materi; (3) proses atau sistem penyampaian materi; dan (4) evaluasi. Keempat komponen kurikulum tersebut baik dalam dokumen maupun implementasi merupakan suatu sistem yang saling berkait erat dan saling mempengaruhi satu sama lainnya. ${ }^{9}$

Dengan demikian kurikulum yang dimaksud bukan hanya dokumen tertulis atau desain mengenai pengaturan tentang tujuan, isi atau materi, proses pembelajaran dan evalusi, tetapi sekolah dan guru mampu memberi jaminan bahwa pengalaman belajar bagi para peserta didik merupakan bagian yang tidak terpisahkan dari desain kurikulum. Pengalaman belajar dirancang dalam kurikulum yang dalam prosesnya jelas semua tahapan belajar yang dilalui oleh siswa, sehingga mereka memiliki pengetahuan dan keterampilan yang menggambarkan kompetensi. Dalam lapangan praksis suatu pendidikan, kurikulum memberikan gambaran pasti tentang cara mencapai tujuan pendidikan yang dijabarkan dalam bahan belajar, dari mana mulai diajarkan dan kapan diakhiri, dan bagaimana cara untuk menguasai bahan ajar agar dapat mencapai kelulusan. Atau dengan singkat dapat dikatakan bahwa kurikulum adalah suatu perencanaan untuk mendapatkan keluaran (out-comes) yang diharapkan dari suatu pembelajaran.

\section{Pendidikan Islam Multikultural}

Praktik penyelenggaran Pendidikan agama Islam telah menyiapkan peserta didik untuk menjadi bagian dari masyarakat ( $a$ part of siciety) yang sesungguhnya. Sedangkan bila dikembangkan dengan tidak mengembangkan hal tersebut sebenarnya pendidikan agama hanya menyiapkan peserta didik yang jauh dari kontek kehidupan sosial yang ada. Sebagai implikasinya, upaya-upaya memperlunak kebekuan dan mencairkan kekakuan pemikiran keagamaan dan kemanusiaan dari masing-masing agama dan budaya belum dianggap terlalu penting untuk digiring ke ranah pendidikan.

\footnotetext{
${ }^{8}$ SK Dirjen Pendis tentag Kurikulum 2013, hal. 8

${ }_{9}^{9}$ Keberadaan empat komponen ini, secara operasional menurut Tyler (1949:1) mengacu pada pertanyaan berikut (1) What educational purposes should the school seek to attain?; (2) What educational experiences can be provided that are likely to attain these purposes?; (3) How can these educational experiences be effectively organized?; dan (4) How can we determine whether theses purposes are being attained?
} 
Mulai dari segi materi sampai metodologi yang diajarkan di sekolah, pesantren, seminari, dan masyarakat umumnya, memiliki kecenderungan untuk mengajarkan pendidikan agama secara parsial (kulitnya saja). Materi pendidikan agama misalnya lebih terfokus pada mengurusi masalah private affairs (al ahwal al syakhsiah) semacam masalah keyakinan seorang hamba dengan Tuhannya face to face. Seakan masalah surga atau kebahagiaan hanya dapat diperoleh dengan ibadah atau akidah saja. Sebaliknya, pendidikan keagamaan kurang peduli dengan isu-isu umum (al-ahwal al-ummah) semacam sikap antikorupsi, wajibnya transformasi sosial, dan kepedulian terhadap sesama. ${ }^{10}$

Ada beberapa prinsip pembelajaran agama berbasis multikultural: (1) Mengajarkan Pendidikan Islam dengan mempertimbangkan pluralitas paham keagamaan peserta didik, (2) Mengajarkan agama Islam dengan mempertimbangkan pluralitas agama yang ada di Indonesia. Artinya, peserta didik diajarkan untuk berpegang teguh pada ajaran agamanya tetapi tetap menghormati agama lain yang dianut oleh peserta didik yang lain. Keyakinan yang teguh terhadap ajaran agama yang dianut tidak menimbulkan kebencian terhadap agama lain. Pendidikan agama dengan perspektif multikultural mengajarkan kepada peserta didik untuk menghormati agama-agama yang hidup dalam masyarakat, tampa berburuk sangka kepada pemeluk agama lain; (3) mengajarkan agama Islam dengan mempertimbangan keragaman kemampuan peserta didik Perbedaan inilah yang harus diakomodasi dalam pembelajaran agama; (4) Mengajarkan agama dengan aspek gender. Karena Islam mengajarkan keseteraan gender maka proses pembelajaran agama harus memperhatikan keadilan gender. ${ }^{11}$

Dalam konteks pendidikan Islam, tujuan pendidikan Islam diarahkan pada pengembangan nilai-nilai islami yang bertungku pada tiga dimensi hubungan manusia sebagai khalifah di muka bumi. Dalam konteks ini maka tujuan pendidikan Islam dirahkan pada usaha sebagai berikut: 1) menanamkan sikap hubungan yang seimbang dan selaras dengan Tuhannya; 2) membentuk sikap hubungan yang harmoni, selaras, dan seimbang dengan masyarakatnya; dan 3) mengembangkan kemampuannya untuk menggali, mengelola, dan memanfaatkan kekayaan alam ciptaan Allah bagi kepentingan kesejahteraan hidupnya dan dan hidup sesamanya serta bagi

${ }^{10}$ Busman Edyar, "RUU Sisdiknas dan Pendidikan Pluralis-Multikultural", dalam Kompas, 31 Maret 2003

${ }^{11}$ H. A.R. Tilaar, Kekuasaan dan Pendidikan, (Magelang: Indonesiatera, 2003). Hal. 18. 
kepentingan ubudiyah kepada Allah dilandasi sikap dan hubungan yang harmonis. ${ }^{12}$

Hampir sama dengan tujuan tersebut diatas, Quraish Shihab berpendapat bahwa kita dapat berkata bahwa tujuan pendidikan AlQur'an (Islam) adalah membina manusia secara pribadi dan kelompok sehingga mampu menjalankan fungsinya sebagai hamba dan khalifahNya, guna membangun dunia ini sesuai dengan konsep yang ditetapkan Allah. Atau dengan kata yang lebih singkat dan sering digunakan oleh al-Qur'an, untuk bertaqwa kepada-Nya. ${ }^{13}$ Tujuan terakhir pendidikan Muslim adalah perwujudan penyerahan mutlak kepada Allah, pada tingkat individual, masyarakat, dan kemanusiaan pada umumnya. ${ }^{14}$

Darai beberapa tinjauan tentang tujuan pendidikan Islam tersebut diatas merupakan penjelasan dari tujuan teringgi dalam Islam, yaitu menjadi manusia bertakwa, manusia yang mampu mewujudkan diri sebagai khalifah dan abdullah sekaligus. Dari pandangan ini melahirkan tujuan takwa dalam arti tunduh dan patuh pada hukum-hukum syari'at Allah swt. sekaligus manusia yang kreatif memanfaatkan hukum-hukum Allah swt. yang berhubungan dengan alam guna melaksanakan fungsi khalifah Allah swt. di muka bumi. Hukum-hukum syariat diketahui dengan mempelajari ilmu-ilmu keislaman, sedangkan hukum-hukum alam semesta atau sunnatullah diketahui dan dipelajari melaui sains berupa ilmu-ilmu ke-alaman dan humaniora.

Dengan demikian pendidikan Islam multukultural pada prinsipnya adalah pemahaman dan pelaksanaan hidup muslim bersama, bergaul dengan sesama manusia, baik sesama muslim maupun dengan non-muslim, yang dalam kenyataan keberadaannya memiliki keragaman, atau tegasnya secara imani dan faktual Allah swt. sengaja menciptakan manusia beragam. Keragaman itu barupa, ras, suku bangsa, budaya maupun agama. Dalam perpektif inilah diperlukan nilai-nilai keberagaman atau multikultural sebagai salah satu tujuan pendidikan Islam. Adapun nilai-nilai Islam yang dapat dikembangkan sebagai tujuan dijadikan dalam pendidikan multikulturalisme antara lain nilai: empati, kasih sayang, kebersamaan, menghargai perbedaan, rela berkorban, tenggang rasa, toleransi, dan tolong menolong. ${ }^{15}$ Nilai-Nilai multikulturalisme dalam bahasa lain, akar-akar inklusif dalam multikulturalisme Islam meliputi

\footnotetext{
12 Muzayyin Arifin, Filsafat Pendidikan Islam, cet. ke-5(Jakarta: Bumi Aksara, 2010), 109

${ }^{13}$ QuraishShihab,MembumikanAl-Qu'an, Bandung: Mizan, 1992,cet. ke-2, hal. 173.

${ }^{14}$ Ali Ashraf, Horison Baru Pendidikan Islam, Jakarta: Pustaka Firdaus, 1993, cet. ke-3, hal.2.

15 Untuk uraian lebih rinci lihat, H.M. Junaidi Ghony, Konsep Dasar Multikulturalisme dalam Kurikulum, Makalah Bahan Perkuliahan, hlm. 198 - 203
} 
nilai; at-ta'aruf atau saling mengenal (Q.S Al-Hujurat. 13), attawassuth atau moderat/adil (Q.S. Al-Baqarah.143), at-tasamuh atau toleran (Q.S. Ali 'Imran, 159), at-ta'awun atau tolong menolong (Q.S. Al-Ma'idah. 2), at-tawazun atau harmoni (Q.S. Al-Qashash. 77)16

\section{Tujuan Pembelajaran Islam Multikultural}

Dari beberapa penjelasan mengenai cakupan pengertian pendidikan, kurikulum dan tujuan pendidikan, dapat dipahami bahwa ketiganya memiliki hubungan yang tak bisa dipisah-pisahkan. Kurikulum memberikan pengarahan dalam mewujudkan tujuan pendidikan, pelaksanaan diwujudkan melalui apa yang disebut dengan pembelajaran. Ini berarti kurikulum dan juga pembelajaran memiliki tujuan masing-masing. Dengan demikian apabila tujuan tersebut dihubungkan maka dapat dimengerti bahawa tujuan pembelajaran adalah tahapan atau pelaksanaan tujuan pendidikan.

Sedangkan menurut jenis perilakunya tujuan dibedakan menjadi tiga yaitu: tujuan berupa kognitif, tujuan-tujuan apektif dan tujuantujuan psikomotorik. Hal tersebut sejalan dengan pendapat Blooms yang mengguna'kan istilah ranah, yaitu ranah kognitif, ranah pasikomotorik dan ranah apektif.

a. Ranah Kognitif, menekankan pada aspek intelektual dan memiliki jenjang dari yang rendah sampai yang tinggi, yaitu: (1). Pengetahuan. Pengetahuan menitik beratkan pada aspek ingatan terhadap materi yang telah dipelajari mulai dari fakta sampai teori. (2). Pemahaman. Pemahaman merupakan langkah awal untuk dapat menjelaskan dan menguraikan sebuah konsep ataupun pengertian. Pemahaman dapat berupa kemampuan dalam memperkirakan, dan menafsirkan. Misalnya : memahami fakta dan prinsip, menafsirkan bahan lisan, menafsirkan bagan, menterjemahkan bahan verbal ke rumus matematika, dan sebagainya. (3). Penerapan (aplikasi). Penerapan merupakan kemampuan untuk menggunakan bahan yang telah dipelajari ke dalam situasi yang baru / nyata. Meliputi : aturan, metode, konsep, prinsip, hukum, teori. Misalnya mampu menerapkan sebuah teori ke dalam situasi yang praktis, mempertunjukan metode dan prosedur tertentu. (4). Analisis (pengkajian). Analisis merupakan kemampuan dalam merinsi bahan menjadi bagian-bagian supaya strukturnya mudah untuk dipahami. Meliputi identifikais bagian-bagian, mengenali prinsip-prinsip tertentu. (5). Sintesis. Adalah kemampuan mengkombinasikan bagianbagian menjadi suatu keseluruhan baru yang menitikberatkan pada tingkah laku kreatif dengan cara

16 Untuk uraian lebih lengkap lihat, M. Tholchah Hasan, Akar-Akar Nilai Inklusif dalam Multikulturalisme Islam, Makalah kuliah Multidisiplin Pendidikan Islam Multikultural. 
memformulasikan pola dan struktur baru. Contoh : menulis cerita pendek yang kreatif, menyusun rencana penelitian, menggunakan bahan-bahan untuk memecahkan masalah. (6). Evaluasi. Adalah kemampuan dalam mempertimbangkan nilai untuk maksud tertentu berdasarkan kriteria internal dan kriteria eksternal. Contoh menilai sebuah karya orang lain, memberikan apresiasi terhadap hasil karya seni, membuat justifikais terhadap sebuah fenomena yang terjadi dalam kehidupan sosial, dan sebagainya. ( revisi taksonomi Bloom,

b. Ranah Afektif, adalah sikap , perasaan, emosi, dan karakteristik moral yang diperlukan untuk kehidupan di masyarakat, dengan demikian ranah ini sangat diperlukan bagi siswa. Ranah afektif terbagi menjadi lima tingkatan, yaitu : (1). penerimaan/receiving, misalnya kemampuan siswa untuk mau mendengarkan materi pembelajaran yang disampaikan oleh guru dan media pembelajaran dengan melibatkan perasaan, antusiasme dan semangat belajar yang tinggi. (2). sambutan /responding : yaitu kemampuan siswa untuk memberikan timbal balik positif terhadap lngkungan dalam pembelajaran misalnya : menanggapi, menyimak, bertanya dan berempai. (3) Menilai / valuing : penerimaan terhadap nilai-nilai yang ditanamkan dalam pembelajaran, membuat pertimbangan terhadap berbagai nilai untuk diyakini dan diaplikasikan. (4). Organisasi, dalam hal ini kemampuan siswa dalam hal mengorganisasi suatu sistem nilai. (5). Karakterisasi dengan suatu kompleks nilai. Misalnya : Siswa menyatukan nilai musik kedalam kehidupan pribadi dan menerapkan konsep tersebut pada hobi pribadinya, minatnya atau juga untuk karirnya.

c. Ranah Psikomotor, adalah kawasan psikomotor yaitu kawasan yang berkaitan dengan aspek-aspek keterampilan jasmani. ${ }^{17}$ Ranah psikomotor kebanyakan dari kita menghubungkan aktivitas motor dengan pendidkan fisik dan atletik, tetapi banyak subjek lain, seperti menulis dengan tangan dan pengolahan kata juga membutuhkan gerakan. ${ }^{18}$ Ranah Psikomotor terdiri antara lain: (1). Persepsi (perception) Kemampuan untuk menggunakan isyarat-isyarat sensoris dalam memandu aktivitas motrik. Penggunaan alat indera sebagai rangsangan untuk menyeleksi isyarat menuju terjemahan. ${ }^{19}$ Misalnya, pemilihan warna. (2). Kesiapan (set) Kemampuan untuk menempatkan dirinya dalam memulai suatu gerakan. kesiapan fisik, mental, dan

17 Dimyati dan Mudjiono, Belajar dan Pembelajaran, hlm. 298.

18 John W. Santrock, Psikologi Pendidikan,terj. Tri Wibowo, hlm.469.

19 Muhammad Yaumi, Prisip-Prinsip Desain Pembelajaran, hlm. 98. 
emosional untuk melakukan gerakan.Misalnya, posisi start lomba lari. (3).Gerakan terbimbing (guided response) Kemampuan untuk melakukan suatu gerakan sesuai dengan contoh yang diberikan. Tahap awal dalam mempelajari keterampilan yang kompleks, termasuk di dalamnya imitasi dan gerakan cobacoba. Misalnya, membuat lingkaran di atas pola. (4). Gerakan yang terbiasa (mechanical response) Kemampuan melakukan gerakan tanpa memperhatikan lagi contoh yang diberikan karena sudah dilatih secukupnya. Membiasakan gerakangerakan yang telah dipelajari sehingga tampil dengan meyakinkan dan cakap. Misalnya, melakukan lompat tinggi dengan tepat. (5). Gerakan yang kompleks (complex response) Kemampuan melakukan gerakan atau keterampilan yang terdiri dari banyak tahap dengan lancar, tepat dan efisien. ${ }^{20}$ gerakan motoris yang terampil yang di dalamnya terdiri dari pola-pola gerakan yang kompleks. Misalnya, bongkar pasang peralatan dengan tepat. (6). Penyesuaian pola gerakan (adjusment) Kemampuan untuk mengadakan perubahan dan menyesuaikan pola gerakan dengan persyaratan khusus yang berlaku. ${ }^{21}$ Keterampilan yang sudah berkembang sehingga dapat disesuaikan dalam berbagai situasi. Misalnya, keterampilan bertanding. (7). Kreativitas (creativity) Kemampuan untuk melahirkan pola gerakan baru atas dasar prakarsa atau inisiatif sendiri. ${ }^{22}$ Misalnya, kemampuannya membuat kreasi tari baru.

Guna mempermudah memahami keterkaitan tujuan dalam taksonomi Bloom dengan pembelajaran sebagaimana dalam tabel berikut ini: 23

\begin{tabular}{|c|c|c|}
\hline Domain & Inti konseptual & $\begin{array}{c}\text { Kemampuan yang } \\
\text { dihasilkan }\end{array}$ \\
\hline Kognitif & $\begin{array}{l}\text { Berisi penguasaan pengetahuan yang } \\
\text { akan dikuasai. } \\
\text { Pertanyaan: kemampuan apa yang saya } \\
\text { harapkan dari murid saya untuk } \\
\text { menguasai pengetahuan tertentu }\end{array}$ & $\begin{array}{l}\text { 1. Conceptualization } \\
\text { 2. Comprehension } \\
\text { 3. Application } \\
\text { 4. Evaluation } \\
\text { 5. Synthesis }\end{array}$ \\
\hline Afeksi & $\begin{array}{l}\text { Berisi tentang penguasaan sebuah } \\
\text { emosi tertentu Pertanyaan: apa yang } \\
\text { saya harapkan pembelajar rasakan atau } \\
\text { pikirkan secara mendalam? }\end{array}$ & $\begin{array}{l}\text { 1. Receiving } \\
\text { 2. Responding } \\
\text { 3. Valuing } \\
\text { 4. Organizing } \\
\text { 5. Characterizing }\end{array}$ \\
\hline
\end{tabular}

20 W. S. Winkel, Psikologi Pengajaran, hlm. 154.

21 Dimyati dan Mudjiono, Belajar dan Pembelajaran, hlm. 30.

22 W. S. Winkel, Psikologi Pengajaran, hlm. 154.

${ }^{23}$ Direktorat Kemahasiswaan dan Pembelajaran Dirjen Pendidikan Tinggi Kementeria Pendidikan dan Kebudayaan, Buku Kurikulum Pendidikan Tinggi, Tahun 2014 , hlm 33-36. 
JURNAL PIWULANG, Vol. I No. 2 Maret 2019, 121-136

\begin{tabular}{|l|l|l|}
\hline Psikomotor & Penguasaan kemampuan fisik/ mekanik & 1. Perception \\
& Pertanyaan: kemampuan fisik apa yang & 2. Simulation \\
& saya harapkan dikuasai oleh pembelajar & 3. Conformation \\
& & $\begin{array}{l}\text { 4. Production } \\
\text { 5. Mastery }\end{array}$ \\
\hline
\end{tabular}

Tabel 1: Tujuan Taksonomi Bloom

Untuk mempermudah menggunakan konsep Bloom tersebut, terutama dalam hal domain kognitif, dibawah ini akan dirangkum dalam tabel yang menjelaskan mengenai penggunaan taksonomi domain kognitif.

\begin{tabular}{|c|l|l|l|}
\hline $\begin{array}{c}\text { Ting } \\
\text { katan }\end{array}$ & Kemampuan & \multicolumn{1}{|c|}{ Definisi } & \multicolumn{1}{|c|}{$\begin{array}{c}\text { Capaian } \\
\text { pembelajaran }\end{array}$} \\
\hline $\mathbf{1}$ & Mengetahui & $\begin{array}{l}\text { Mengingat, memanggil } \\
\text { informasi }\end{array}$ & $\begin{array}{l}\text { Sebutkan, ceritakan, } \\
\text { kenali, menyebutkan } \\
\text { kembali }\end{array}$ \\
\hline $\mathbf{2}$ & Memahami & $\begin{array}{l}\text { Memahami maksud } \\
\text { sebuah konsep }\end{array}$ & $\begin{array}{l}\text { Merangkum, } \\
\text { mengkonversi, } \\
\text { mempertahankan, } \\
\text { menyatakan kembali }\end{array}$ \\
\hline $\mathbf{3}$ & Mengaplikasikan & $\begin{array}{l}\text { Menggunakan konsep } \\
\text { pada situasi yang } \\
\text { berbeda }\end{array}$ & $\begin{array}{l}\text { Menghitung, } \\
\text { menyiapkan, } \\
\text { Moncontoh }\end{array}$ \\
\hline $\mathbf{4}$ & Menganalisis & $\begin{array}{l}\text { Membagi informasi } \\
\text { menjadi beberapa } \\
\text { konsep untuk dipahami }\end{array}$ & $\begin{array}{l}\text { Bandingkan, uraikan, } \\
\text { bedakan, pisahkan }\end{array}$ \\
\hline $\mathbf{5}$ & Mensintesis & $\begin{array}{l}\text { Menyatukan beberapa } \\
\text { konsep untuk } \\
\text { membangun konsep } \\
\text { baru }\end{array}$ & $\begin{array}{l}\text { Menggeneralisir, } \\
\text { mengkategorisasikan }\end{array}$ \\
\hline $\mathbf{6}$ & Mengevaluasi & $\begin{array}{l}\text { Menilai sebuah konsep } \\
\text { Menilai, mengkritik, } \\
\text { beragumentasi }\end{array}$ \\
\hline
\end{tabular}

Tabel 2: penguasaan pengetahuan (domain kognitif)

Sebenarnya, dalam pembahasan taksonomi pendidikan, disamping kerangka taksonomi Bloom, juga dikenal taksonomi pembelajaran Anderson dan tasonomi Marzano. Untuk sekedar memberikan gambaran perbedaan dengan taksonomi Bloom, berikut tabel taksonomi pembalajaran Marzano sbb: ${ }^{24}$

${ }^{24}$ Informasi tentang kedua taksonomi pembelajaran tersebut, diantaranya lihat, pedoman kurikulum pendidikan Tinggi, ibid. 


\begin{tabular}{|c|c|c|}
\hline \multirow[t]{2}{*}{ Informasi } & Pengaturan ide & $\begin{array}{ll} & \text { Prinsip } \\
\circ & \text { Generalisasi }\end{array}$ \\
\hline & Detail & $\begin{array}{ll}\text { ○ } & \text { Sekuensi/urutan waktu } \\
\circ & \text { Fakta } \\
\circ & \text { Istilah/makna kata } \\
\end{array}$ \\
\hline \multirow{2}{*}{$\begin{array}{l}\text { Prosedur } \\
\text { Mental }\end{array}$} & Proses & ○ Prosedur makro \\
\hline & Ketrampilan & $\begin{array}{ll} & \text { Taktik } \\
\circ & \text { Algoritma } \\
\circ & \text { Hukum logika sederhana }\end{array}$ \\
\hline \multirow{2}{*}{$\begin{array}{l}\text { Prosedur } \\
\text { Psikomotor }\end{array}$} & Proses & $\circ$ Prosedur kombinasi kompleks \\
\hline & Skills & $\begin{array}{l}\text { P Prosedur kombinasi sederhana } \\
\circ \text { Prosedur dasar fundamental }\end{array}$ \\
\hline
\end{tabular}

Tabel 3:

Komponen domain pengetahuan sesuai Taksonomi Marzano (2007).

\section{Taksonomi pembelajaran dengan pengukuran kompetensi peserta didik.}

Sebagaimana pemaparan tentang pendidikan Islam multikultural diatas, yang pada prinsipnya pendidikan Islam multikultural berarti usaha sadar terencana mewujudkan kompetensi peserta didik yang dapat mengamalkan nilai-nilai Islam multikultural, nilai at-ta'aruf (saling mengenal), at-tawassuth (moderat/adil), attasamuh (toleran), at-ta'awun (tolong menolong) at-tawazun (harmoni).

Kalau dicermati nilai-nilai multikulturalisme Islam tersebut dapat dikategorikan sebagai salah satu tujuan akhir dari pendidikan Islam. Agar tujuan akhir tersebut dapat dilaksanakan dalam pembelajaran diperlukan penjabaran sesuai dengan hirarki tujuan pembelajaran. Tujuan pencapaian pembelajaran dalam kurikulum disebut sebagai kompetensi. Guna memperjelas hubungan tujuan dengan taksonomi pembelajaran, berikut ini penulis sajikan nilai toleransi sebagai salah satu kompetensi pembelajaran Al-Quran Hadits di Madrasah Aliyah, sesuai dengan standar kurikulum 2013 sebagaimana KMA 165 tahun 2014. ${ }^{25}$

Tujuan dan Ruang Lingkup Kelompok Mata Pelajaran PAI dan Bahasa Arab di Madrasah Aliyah. Mata pelajaran al-Qur'an-Hadis bertujuan untuk: a) Meningkatkan kecintaan peserta didik terhadap al-Qur'an dan Hadis, b) Membekali peserta didik dengan dalil-dalil yang terdapat dalam al-Qur'an dan hadis sebagai pedoman dalam menyikapi dan menghadapi kehidupan, c) Meningkatkan pemahaman dan pengamalan isi kandungan al-Qur'an dan hadis yang dilandasi

${ }^{25}$ Lampiran KMA 165 hal. 49 - 51 
oleh dasar-dasar keilmuan tentang al-Qur'an dan Hadis. Adapun tematema yang ditinjau dari perspektif al-Qur'an dan Hadis, terdiri dari 15 (lima belas) tema, yaitu: (1). Manusia dan tugasnya sebagai khalifah di bumi. (2). Demokrasi dan musyawarah mufakat. (3). Keikhlasan dalam beribadah. (4). Nikmat Allah dan cara mensyukurinya. (5). Perintah menjaga kelestarian lingkungan hidup. (6). Pola hidup sederhana dan perintah menyantuni para duafa.(7). Berkompetisi dalam kebaikan. (8). Amar ma'ruf nahi munkar. (9). Ujian dan cobaan manusia. (10). Tanggung jawab manusia terhadap keluarga dan masyarakat. (11). Berlaku adil dan jujur. (12). Toleransi dan etika pergaulan. (13). Etos kerja. (14). Makanan yang halal dan baik. (15). Ilmu pengetahuan dan teknologi. ${ }^{26}$

Teori mengenai kompetensi dan kurikulum berbasis kompetensi diarahkan kepada pikiran pokok bahwa konten kurikulum adalah kompetensi, dan kompetensi diartikan sebagai kemampuan melakukan sesuatu (ability to perform) berdasarkan sikap, keterampilan, dan pengetahuan. ${ }^{27}$ Dengan demikian maksud utama kurikulum berbasis kompetensi pelaksanaan pendidikan berorientasi pada jaminan kemampuan kepada peserta didik sesuai dengan tingkat pendidikan dan bidang kajian. Disamping itu seluruh proses pendidikan dijalankan sesuai dengan standar pendidikan yang telah ditetapkan. ${ }^{28}$ Hirarki penjabaran kompetensi tertinggi dalam jalur atau tingkat pendidikan dirumuskan dalam SKL (Standar Kelulusan) Kompetensi Inti (KI) dan Kompetensi dasar (KD).

Contoh Kompetensi Dasar (KD) Mata Pelajaran Al-Quran Hadits Kelas XI.

1.5 Menghayati kandungan Al-Qur'an tentang toleransi dan etika pergaulan

2.5 Memiliki sikap toleransi dan etika pergaulan sesuai kandungan Al-Qur'an dalam QS. al-Kafirun [109]: 1-6; QS. Yunus (10): 4041; QS. al-Kahfi [18]: 29; QS. al-Hujurat [49]: 10-13; QS. Ali 'Imran (3): 103, QS. al-Mujadilah [58]:11

3.5 Memahami kandungan Al-Qur'an tentang toleransi dan etika pergaulan dalam QS. al-Kafirun [109]: 1-6; QS. Yunus (10): 4041; QS. al-Kahfi [18]:29; QS. al-Hujurat [49]: 10-13; QS. ali 'Imran (3): 103, QS. al-Mujadilah [58]: 11

4.5 Menunjukkan contoh perilaku bertoleransi dan beretika dalam pergaulan sesuai kandungan QS. al-Kafirun [109]: 1-6; QS. Yunus

\footnotetext{
${ }^{26}$ Lampiran KMA 165 hal 52 -

${ }^{27}$ SK Dirjen Pendis tentang Kurikulum 2013, hal. 6

28 Paling tidak di Indonesia sekarang telah diberlakukan Standar Nasional Pendidikan, yaitu 8 (delapan) Stnadar Nasional Pendidikan, diantaranya: standar isi, proses, sarana dll.
} 
(10):40-41; QS. al-Kahfi [18]: 29; QS. al- Hujurat: 10-13; QS. ali 'Imran (3):103, QS. al-Mujadilah [58]: 11

Dari rumusan beberapa Kompetensi Dasar tersebut diatas, menggambarkan kemampuan minimal kemampuan atau kompetensi yang wajib ditagih atau di tunjukkan (perform) oleh peserta didik. Dengan menggunakan taksonomi pembelajaran Bloom, kemampuan atau capaian pembelajaran dapat diukur keberhasilannya. Dengan demikian taksonomi tujuan pembelajaran digunakan untuk menyusun tujuan dan sekaligus mengukur ketercapaian hasil pembelajaran atau kompetensi.

\section{PENUTUP}

Cakupan pengertian kurikulum dapat diartikas secara luas maupun secara sempit maupun secara luas. Secara pendek kurikulum dapat diartikan sebagai kajian atau sejumlah mata pelajaran untuk mencapai kelulusan tertentu, atau rencana pembelajaran yang dilakukan dalam waktu tertentu. Dalam pengertian yang luas kurikulum bukan hanya sekedar memuat sejumlah mata pelajaran, akan tetapi termasuk pula di dalamnya segala usaha sekolah untuk mencapai tujuan yang diinginkan, baik usaha tersebut dilakukan di lingkungan sekolah maupun di luar sekolah, yang berupa sejumlah pengalaman pendidikan, kebudayaan, sosial, olah raga, dan kesenian baik yang berada di dalam maupun di luar kelas yang dikelola oleh sekolah.

Kurikulum pendidikan Islam multikultural bukan sekedar memberikan pengalaman melalui pembelajaran tentang nilai-nilai Islam, tetapi juga meliputi penciptaan lingkungan belajar yang kondusif untuk menumbuhkan sikap dan perilaku multikultural serta dilaksanakan oleh orang-orang yang menjunjung tinggi nilai-nilai keadilan yang berkemanusiaan.

Tujuan pendidikan yang berisi nilai-nilai Islam multikultural seharusnya dirumuskan secara hirarkis sesuai tujuan pendidikan, mulai dari tujuan filosofis religius, normatif, institutif, akademis, dan tujuan operasional pembelajaran. Perumusan tujuan demikian untuk lebih menjamin pencapaian kompetensi peserta didik.

\section{DAFTAR RUJUKAN}

A. Fuad Fanani, 2004, Islam Mazhab Kritis: Menggagas Keberagamaan Liberati, Jakarta: Kompas Gramedia.

Abdurrahman Saiih Abdullah, tt, Educational Theory a Quranic Outlook, Makkah al-Mukarramah: Umm al-Qura University.

Ahmad D. Marimba, 1962, Pengantar Filsafat Pendidikan Islam, Bandung: PT. Al-Ma'arif. 
JURNAL PIWULANG, Vol. I No. 2 Maret 2019, 121-136

Ainul Yaqin, 2005, Pendidikan Multikultural Cross-cultural Understanding untuk Demokrasi dan Keadilan, Yogyakarta: Pilar Media.

Ali Ashraf, 1993, Horison Baru Pendidikan Islam, Jakarta: Pustaka Firdaus, cet. ke-3

Alwi Shihab, 1993, Islam Inklusif: Menuju Sikap Terbuka dalam Beragama, Bandung: Mizan.

Busman Edyar, 2003, RUU Sisdiknas dan Pendidikan Pluralis-Multikultural", dalam Kompas, 31 Maret 2003

Crow and Crow, 1990, Pengantar llmu Pendidikan, Yogvakarta: Rake Sarasin, edisi III.

Dimyati dan Mudjiono, 1995, Belajar dan Pembelajaran, Bandung, Remajarosdakarya.

Direktorat Kemahasiswaan dan Pembelajaran Dirjen Pendidikan Tinggi Kementeria Pendidikan dan Kebudayaan, 2014, Buku Kurikulum Pendidikan Tinggi, Tahun 2014

Geneva Gay, 1994, A Synthesis of Scholarship in Multicultural Education, dalam Urban Education Monograph Series, (Washington, NCREL's Urban Education Program.

H. A.R. Tilaar, 2003, Kekuasaan dan Pendidikan, Magelang: Indonesiatera.

Hamim Ilyas, 2005, Multikulturalisme dalam Islam: Memahami Prinsip, Nilai dan Tujuan Multikulturalisme dalam Islam untuk Mencapai Kualitas Keterpilihan, Yogyakarta: Idea Press.

Hasan Langgulung, 1987, Asas-asas Pendidikan Islam, Jakarta: Pustaka AlHusna cet. ke-1.

Jalaluddin \& Said, Usman. 1994. Filsafat Pendidikan Islam: Konsep dan Perkembangan Pemikirannya. Jakarta: PT. Raja Grafindo Persada.

John W. Santrock, 2007. Psikologi Pendidikan, terj. Tri Wibowo Jakarta:Kencana.

Lihat Abdul Hadi WM, 2008, Multikulturalisme vs Nation-State', dalam Titik Temu: Jurnal Dialog Peradaban, Jakarta: Nurcholish Madjid Society, Vol. I, Nomor 1, 136.

Malik Fadjar, 1995, Pengembangan Pendidikan Islam dalam Kontektualisasi Ajaran Islam, Jakarta: IPHI dan Paramadina.

Muhammad Yaumi, 2013, Prisip-Prinsip Desain Pembelajaran, Jakarta: Kencana.

Muzayyin Arifin, 2010, Filsafat Pendidikan Islam, cet. ke-5, Jakarta: Bumi Aksara.

Ngainun Naim dan Achmad Sauqi, 2011, Pendidikan Multikultural Konsep dan Aplikasi, Ar-Ruzz Media. Jogjakarta.

Quraish Shihab, 1992, MembumikanAl-Qu'an, Bandung: Mizan, cet. ke-2.

Redja Mudyahardjo, 2001, Filsafat Ilmu Pendidikan suatu Pengantar, Bandung,

PT Remaja Rosdakarya.

S. Nasution. 1991, Pengembangan Kurikulum, Bandung: Citra Adirva Bakti. 
JURNAL PIWULANG, Vol. I No. 2 Maret 2019, 121-136

St.Nugroho, 2005, Multikulturalisme, dalam Andre Ata Ujan, Multikulturalisme: Belajar Hidup Bersama dalam Perbedaan.

Sukmadinata, Nana, 2004, Landasan Psikologi Proses Pendidikan, Rosdakarya, Bandung.

W. S. Winkel, 1995, Psikologi Pengajaran, Jakarta, Gramedia.

Zakiyuddin Baidlowy, 2005, Pendidikan Agama Benvawasan Multikulturalisme, Jakarta: Erlangga. 